\title{
MOLECULAR CHARACTERIZATION OF CAMPYLOBACTER SPECIES FROM TURKEYS FLOCKS IN DELTA GOVERNMENTS
}

\author{
KHALIL, M.R. ${ }^{1}$; AMIRA, A. MOAWAD ${ }^{2 ;}$ KAFAFY, M.H. ${ }^{3}$; HANAN, A. FAHMY ${ }^{4}$ and \\ MONA, M. SOBHY ${ }^{5}$ \\ ${ }^{1}$ Poultry Dis. Animal Health Research Inst. (AHRI), Mansoura Branch, ARC. \\ ${ }^{2}$ Microbiology, AHRI. Mansoura Branch, ARC. \\ ${ }^{3}$ Pox Vaccines Dept. Vaccines and Serum Veterinary Res. Inst., Abassia, ARC, Egypt. \\ ${ }^{4}$ Biotechnology Dept. AHRI, Dokki, ARC. Egypt. \\ ${ }^{5}$ Reproductive Diseases Dept. ARRI. ARC, Giza, Egypt.
}

Received: 31 December 2019; Accepted: 28 January 2020

\begin{abstract}
Two hundred and forty samples were collected from turkey farms and various markets in Delta Governorates for Campylobacter spp. isolation. Multiplex PCR assay was used to identify 2 Thermophilic Campylobacter species (C. jejuni and C. coli). The prevalence of Campylobacter in turkeys (22.5\%) observed in this study; $C$. jejuni was $15.4 \%$ and $C$. coli $7 \%$. The high incidence of Campylobacter in liver was (30\%) followed by skin (26.7\%), cloacal swabs (21.3\%) and finally intestinal content (16.7\%). A food borne disease infected with campylobacteriosis resulting from consuming or handling of contaminated poultry meat. The high incidence of Campylobacter due to contamination to intestinal tract during evisceration can lead to direct contamination of the carcasses or indirectly through the hands of the processors, material or instrument used in processing. The amplification of the DNA belonging to Campylobacter genus specific (C. jejuni hipO) was (19\%); $(13.8 \%) C$. jejuni at $323 \mathrm{bp}$ and $(5.8 \%) C$. coli at $126 \mathrm{bp}$, while for $C$. jejuni 23S rRNA at $650 \mathrm{bp}$. PCR analysis for detection of Campylobacter can be utilized as a simple, rapid and sensitive tool to discriminate stains recovered from different sources, especially when used as profile analysis for a control strategy of $C$. jejuni in turkey farms to reduce the risk of human exposure to Campylobacter and is an important food safety issue. Multiplex PCR was found to be more reliable than the conventional cultural methods in species level for identification of Campylobacter isolates. Further epidemiological studies at different geographical areas, carried to discover the prevalence, magnitude and importance of Campylobacter infection in turkey farms.
\end{abstract}

Keywords: Campylobacter, Turkey, multiplex PCR.

\section{INTRODUCTION}

Campylobacteriosis is considered as the major important zoonotic gastrointestinal disease around the world caused mainly by $C$. jejuni (Gormley et al., 2008). Campylobacter species mainly $C$. jejuni and $C$. coli cause acute human gastroenteritis (Friedman et al., 2000). C. jejuni is part of normal intestinal flora of poultry and is present within the first few days post-hatch. The avian intestine seems to be a favourable environment for proliferation of $C$. jejuni (Lee and Newell 2006).

Campylobacter species are recognized as the most common cause of foodborne bacterial gastroenteritis in human (Nguyen et al., 2016). Campylobacteriosis

Corresponding author: Dr. MONA, M. SOBHY

E-mail address: monagabr17@yahoo.com

Present address: Reproductive Diseases Dept. ARRI. ARC, Giza, Egypt. are predominantly caused by the Thermophilic Campylobacter including $C$. jejuni and $C$. coli (Griffiths and Park, 1990). The main route of infection is ingestion of food of animal origin and particularly consumption of poultry meat (Butzler and Oosterom 1991).

Campylobacter has been found to contaminate $81 \%$ of fresh, whole broiler chicken carcasses and a third of turkey carcasses (Anonymous, 2007). Campylobacter is present in the crop and ceca contents; thus, a single rupture early in processing can contaminate carcasses from several flocks (Musgrove et al., 2001).

Thermophilic Campylobacter species have Gram negative cell wall with capsule and flagella. The bacteria are slender, curved rod to small spiral shape with $0.2-0.5 \mathrm{~mm}$ width and 0.5-5.0 $\mathrm{mm}$ length. They need microaerophilic atmosphere at $37-42^{\circ} \mathrm{C}$ for $48 \pm$ 
4 hours for optimal growth (Shane and Harrington, 1998).

Campylobacter can colonize normally in the intestine, so it can directly contaminate the meat product during evisceration inside the slaughter houses and is the major source of transmission of disease to human (Rahimi and Tajbakhsh, 2008). Meat of broilers, turkeys, and ducks are major sources of $C$. jejuni for humans (Friesema et al., 2012). Turkey products are an important commercial poultry commodity and limited information is available on colonization of turkeys with Campylobacter.

Campylobacters increased from day 1 to day 14 in the carriage rate and diarrhea. By day 39 , the excretion rate had reached $6 \times 10$ (7) campylobacters in fresh faeces, peaks in Campylobacter numbers on days 19 and 75, corresponding to peaks in diarrheic samples (Wallace et al., 1998). The introduction of new birds resulted in an increase in Campylobacter in birds with diarrhea. Turkeys at slaughter showed increased of Campylobacter from beak and highest in caeca (Zhao et al., 2001). Up to $34.9 \%$ of examined turkey carcasses were positive for Campylobacter after chilling (Logue et al., 2003).

Birds infected with Campylobacter will contaminate the food processing environment. The concentration of Campylobacter on turkey carcasses and in caeca is positively correlated to human campylobacteriosis cases (Rosenquist et al., 2003 and Anonymous, 2007). Campylobacter will have a positive impact on consumers' perceptions related to food safety, the food industry and public health agencies (Wassenar et al., 2007).

When considering the overall burden of campylobacteriosis, in addition to the corresponding acute morbidity and mortality described above as well as the long-term post-infectious squealed a consideration must also be made regarding antimicrobial resistance (AMR) (Poly et al., 2019).

In USA, over two million cases of Campylobacter related illness are reported annually. Campylobacter infections being responsible for $5 \%$ of food-related deaths (Mead et al., 1999). In 2004, the incidence of Campylobacter infection in the European Union exceeded than of Salmonella infection for the first time (Zoonotic Agents, 2005). Chicken meat has been reported to be contaminated with Campylobacters up to $100 \%$ the major sources of infection of C. jejuni (Borck and Pedersen, 2005).

Turkey meat is increasingly being chosen by consumers because the adherence to low-fat diets. The consumption of turkey meat has increased in recent times. It is of great importance to identify and assess the potential risks arising from turkey products. The aim of this study was to examine turkey flocks and turkey meat retail products in Delta Governorates for the prevalence of Campylobacter by convential cultural method and molecular characterization.

\section{MATERIALS AND METHODS}

\section{1- Sampling:}

Two hundred and forty samples were collected from turkeys (150 cloacal swabs from turkey farms and 90 samples from freshly slaughtered turkeys from various markets) in Delta Governorates from May 2018 till June 2019 for Campylobacter spp. isolation (Table, I). The samples were cultured onto thioglycollate media within four hours (Smibert, 1974).

Table I: Number and types of examined samples of turkeys for Campylobacter Spp.

\begin{tabular}{|c|c|c|c|c|c|}
\hline \multirow[b]{2}{*}{$\begin{array}{c}\text { Delta } \\
\text { Governorates }\end{array}$} & \multirow[b]{2}{*}{$\begin{array}{c}\text { No. of examined } \\
\text { samples }\end{array}$} & \multirow{2}{*}{$\begin{array}{c}\text { Turkey Farms } \\
\begin{array}{c}\text { No. of Cloacal } \\
\text { Samples }\end{array}\end{array}$} & \multicolumn{3}{|c|}{ Freshly slaughtered turkey } \\
\hline & & & $\begin{array}{c}\text { Intestinal } \\
\text { content }\end{array}$ & Liver & skin \\
\hline Sharkia & 50 & 35 & 5 & 5 & 5 \\
\hline Dakahlia & 75 & 45 & 10 & 10 & 10 \\
\hline Gharbia & 65 & 35 & 10 & 10 & 10 \\
\hline Kafr El-Shaikh & 50 & 35 & 5 & 5 & 5 \\
\hline Total & 240 & 150 & 30 & 30 & 30 \\
\hline
\end{tabular}

\section{2- Isolation and identification of Campylobacter} isolates:

A loop full from each sample were cultured directly onto thioglycollate medium for 24-72 hours in sterile tubes, then a loop full from each tube was cultured on modified Campylobacter blood free selective medium with antibiotics and 10\% sheep blood. All inoculated plates were incubated in microaerophilic condition contain $\mathrm{CO}_{2}(10 \%), \mathrm{O}_{2}(5 \%)$ and $\mathrm{N}_{2}(85 \%)$ in $37^{\circ} \mathrm{C}$ for 48 hours and were demonstrated for characteristics colonies. The suspected colonies will be identified by biochemical test described by ElGohary (1998). 


\section{3- Multiplex PCR assay:}

Extraction of bacterial DNA from Campylobacter species was performed in a $0.5 \mathrm{ml}$ Eppendorf tube containing PBS by heating at $100^{\circ} \mathrm{C}$ for $10 \mathrm{~min}$ in a heat block according to OIE (2008). After centrifugation DNA was collected and stored till used. Quantification of genomic DNA extracted from Campylobacter isolates by using UV Visible Spectrophotometer.

Oligonucleotides primers used were supplied from Metabion (Germany) are listed in Table (2), according to Wang et al. (2002).

DNA amplification of Campylobacter: The amplification of DNA in a $50 \mu$ reaction containing thermoscientific Taq for Multiplex PCR Master Mix (2X) was carried out in Bio-RAD thermo cycler with positive and negative controls and cycling condition was illustrated in Table (3).

Detection of PCR products using agarose gel electrophoresis:

The amplified PCR products were electrophosed on $1.5 \%$ agarose gel (Applichem, Germany, $\mathrm{GmbH}$ ) in 1x TBE buffer with ethidium bromide. For gel analysis, $10 \mu \mathrm{l}$ of the products was loaded in each gel slot. Thermoscientific, Gene Ruler 100 bp ladder was used to determine the expected fragment sizes (Sambrook et al., 1989). The gel was photographed by a gel documentation system (Alpha Innotech, Biometra).

Table 2: Oligonucleotides primers used for detection of Campylobacter strains in Turkey by Multiplex PCR.

\begin{tabular}{|c|c|c|c|c|c|c|}
\hline $\begin{array}{c}\text { Primer } \\
\text { name }\end{array}$ & Target gene & Sequence $\left(5^{\prime}-3^{\prime}\right)$ & $\begin{array}{c}\text { Accession } \\
\text { No. } \\
\end{array}$ & $\begin{array}{c}\text { Gene } \\
\text { location }\end{array}$ & $\begin{array}{l}\text { size } \\
\text { (bp) }\end{array}$ & Reference \\
\hline $23 \mathrm{SE}$ & \multirow{3}{*}{$\begin{array}{c}\text { C. jejuni } 23 \mathrm{~S} \\
\text { rRNA }\end{array}$} & TATACCGGTAAGGA & \multirow{3}{*}{ Z29326 } & $3807-3820$ & \multirow{3}{*}{650} & \multirow{9}{*}{$\begin{array}{l}\text { Wang et } \\
a l ., 2002\end{array}$} \\
\hline $25 \mathrm{SF}$ & & GTGCTGGAG & & $3801-5829$ & & \\
\hline 23SR & & $\begin{array}{c}\text { ATCAATTAACCTTC } \\
\text { GAGCACCG }\end{array}$ & & $4456-4435$ & & \\
\hline CIF & \multirow{3}{*}{ C. jejuni hipO } & ACTTCTTTATTGCTT & \multirow{3}{*}{ Z36940 } & $1662-1681$ & \multirow{3}{*}{323} & \\
\hline $\mathrm{CJF}$ & & GCTGC & & $1002-1081$ & & \\
\hline CJR & & $\begin{array}{c}\text { GCCACAACAAGTAA } \\
\text { AGAAGC }\end{array}$ & & 1984-1965 & & \\
\hline$C C F$ & \multirow{3}{*}{ C. coli glyA } & GTAAAACCAAAGCT & \multirow{3}{*}{ AF136494 } & $337-357$ & \multirow{3}{*}{126} & \\
\hline$C C F$ & & TATCGTG & & ו & & \\
\hline CCR & & $\begin{array}{c}\text { TCCAGCAATGTGTG } \\
\text { CAATG }\end{array}$ & & $462-444$ & & \\
\hline
\end{tabular}

Table 3: Cycling conditions of the primers during PCR according to (Wang et al., 2002).

\begin{tabular}{lccc}
\hline \multicolumn{1}{c}{ Step } & Temperature & Time & Number of cycles \\
\hline 1. Primary denaturation & $94^{\circ} \mathrm{C}$ & $6 \mathrm{~min}$. & 1 cycle \\
\hline 2. Cycling & & & \multirow{2}{*}{35 cycles } \\
\hline A. Secondary denaturation & $95^{\circ} \mathrm{C}$ & $30 \mathrm{sec}$. & \\
\hline B. Annealing & $59^{\circ} \mathrm{C}$ & $30 \mathrm{sec}$. & \\
\hline C. Extension & $72^{\circ} \mathrm{C}$ & $30 \mathrm{sec}$. & \\
\hline 3. Final extension & $72^{\circ} \mathrm{C}$ & $7 \mathrm{~min}$. & 1 cycle \\
\hline
\end{tabular}

\section{RESULTS}

Table 4: Detection of $C$. jejuni and $C$. coli in turkey samples by conventional cultural method.

\begin{tabular}{|c|c|c|c|c|c|c|c|}
\hline \multirow{3}{*}{ Delta Governorates } & \multirow{3}{*}{$\begin{array}{l}\text { No. of the } \\
\text { examined } \\
\text { samples }\end{array}$} & \multirow{2}{*}{\multicolumn{2}{|c|}{$\begin{array}{l}\text { No. of positive } \\
\text { samples }\end{array}$}} & \multicolumn{4}{|c|}{ Conventional cultural methods } \\
\hline & & & & \multicolumn{2}{|c|}{ C. jejuni } & \multicolumn{2}{|c|}{ C. coli } \\
\hline & & No. & $\%$ & No. & $\%$ & No. & $\%$ \\
\hline Sharkia & 50 & 10 & 20 & 6 & 12 & 4 & 8 \\
\hline Dakahlia & 75 & 18 & 24 & 12 & 16 & 6 & 8 \\
\hline Gharbia & 65 & 14 & 21.5 & 9 & 13.8 & 5 & 7.7 \\
\hline Kafr El-Shaikh & 50 & 12 & 24 & 10 & 20 & 2 & 4 \\
\hline Total & 240 & 54 & 22.5 & 37 & 15.4 & 17 & 7 \\
\hline
\end{tabular}


Table 5: Occurrence of Campylobacter jejuni and Campylobacter coli in different turkey samples.

\begin{tabular}{cccccccc}
\hline \multirow{2}{*}{$\begin{array}{c}\text { Types of examined } \\
\text { turkey samples }\end{array}$} & $\begin{array}{c}\text { No. of } \\
\text { examined } \\
\text { samples }\end{array}$ & \multicolumn{2}{c}{$\begin{array}{c}\text { Pampylobacter } \\
\text { species }\end{array}$} & $\begin{array}{c}\text { Campylobacter } \\
\text { jejuni }\end{array}$ & \multicolumn{2}{c}{ Campylobacter coli } \\
\cline { 3 - 8 } & & No. & $\%$ & No. & $\%$ & No. & $\%$ \\
\hline Cloacal samples & 150 & 32 & 21.3 & 24 & 16 & 8 & 5.3 \\
\hline Intestinal content & 30 & 5 & 16.7 & 4 & 13.3 & 1 & 3.3 \\
\hline liver & 30 & 9 & 30 & 5 & 16.7 & 4 & 13.3 \\
\hline skin & 30 & 8 & 26.7 & 4 & 13.3 & 4 & 13.3 \\
\hline Total & 240 & 54 & 22.5 & 37 & 15.4 & 17 & 7 \\
\hline
\end{tabular}

Table 6: Biochemical tests to differentiate between $C$. jejuni and C. coli.

\begin{tabular}{|c|c|c|}
\hline Characteristics & C. jejuni & C. coli \\
\hline Oxidase & + & + \\
\hline Catalase & + & + \\
\hline Nitrate reduction & + & + \\
\hline Urease & -- & -- \\
\hline Hippurate hydrolysis & + & -- \\
\hline \multicolumn{3}{|l|}{ Growth at: } \\
\hline $37{ }^{\circ} \mathrm{C}$ & + & + \\
\hline $43^{\circ} \mathrm{C}$ & + & + \\
\hline Growth at $1 \%$ glycine & + & + \\
\hline \multicolumn{3}{|l|}{ Susceptibility to: } \\
\hline Nalidixic acid & $\mathbf{S}$ & $\mathbf{S}$ \\
\hline Cephalothin & $\mathbf{R}$ & $\mathbf{R}$ \\
\hline
\end{tabular}

Table 7: Incidence of Campylobacter jejuni and Campylobacter coli by multiplex PCR.

\begin{tabular}{cccccccc}
\hline \multirow{2}{*}{$\begin{array}{c}\text { Types of examined } \\
\text { turkey samples }\end{array}$} & $\begin{array}{c}\text { No. of } \\
\text { examined } \\
\text { samples }\end{array}$ & \multicolumn{2}{c}{$\begin{array}{c}\text { Positive } \\
\text { Campylobacter } \text { spp. }\end{array}$} & $\begin{array}{c}\text { Campylobacter } \\
\text { jejuni }\end{array}$ & \multicolumn{2}{c}{$\begin{array}{c}\text { Campylobacter } \\
\text { coli }\end{array}$} \\
\cline { 2 - 8 } & & No. & $\%$ & No. & \% & No. & $\%$ \\
\hline Cloacal samples & 150 & 30 & 20 & 22 & 14.7 & 8 & 5.3 \\
\hline Intestinal content & 30 & 3 & 10 & 2 & 6.7 & 1 & 3.3 \\
\hline liver & 30 & 8 & 26.7 & 5 & 20 & 3 & 10 \\
\hline skin & 30 & 6 & 20 & 4 & 13.3 & 2 & 6.7 \\
\hline Total & 240 & 47 & 19.6 & 33 & 13.8 & 14 & 5.8 \\
\hline
\end{tabular}

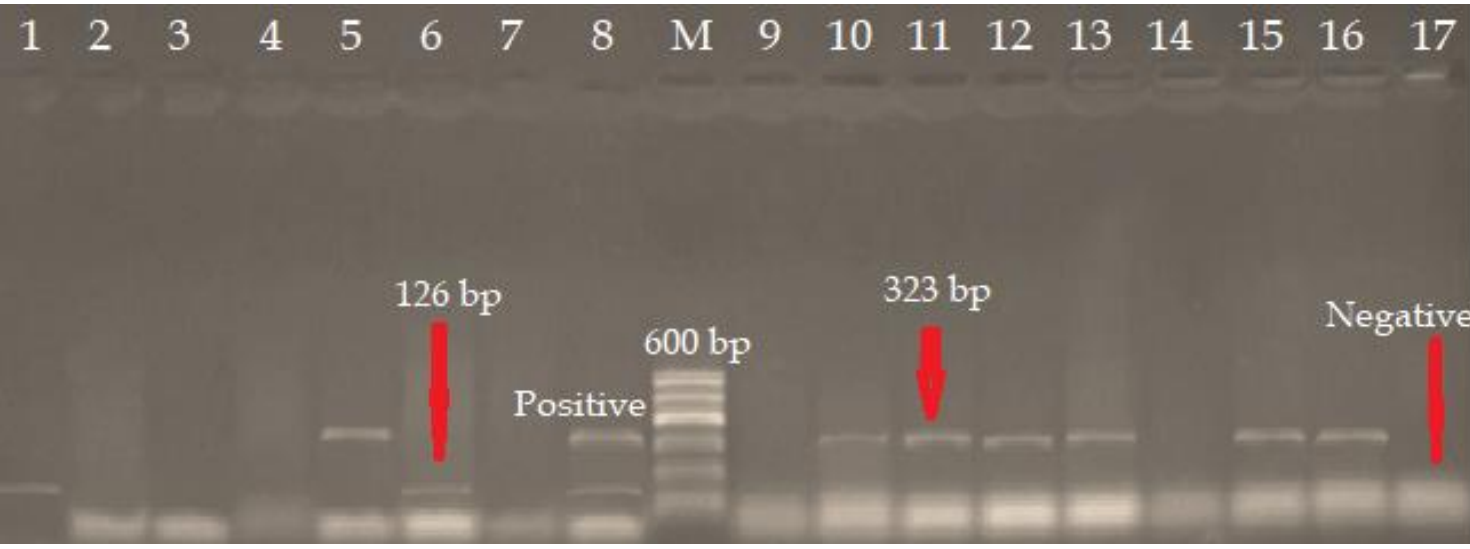

Fig. (1): Multiplex PCR of $C$. jejuni hipO and C. coli were detected in turkey samples in $1.5 \%$ agarose gels electrophoresis. All the 47 Campylobacter isolates yielded the genus specific as 31 isolates of C. jejuni at $323 \mathrm{bp}$ while 14 produced the $C$. coli at $126 \mathrm{bp}$. Lane 1 and 6 samples positive of $C$. coli. Lane: 5,10,11,12,13,15 and 16 samples positive of $C$. jejuni. M: 100-600 bp ladders; Lane 8: Positive controls of C. jejuni and C. coli. Lane 7: Negative control. 


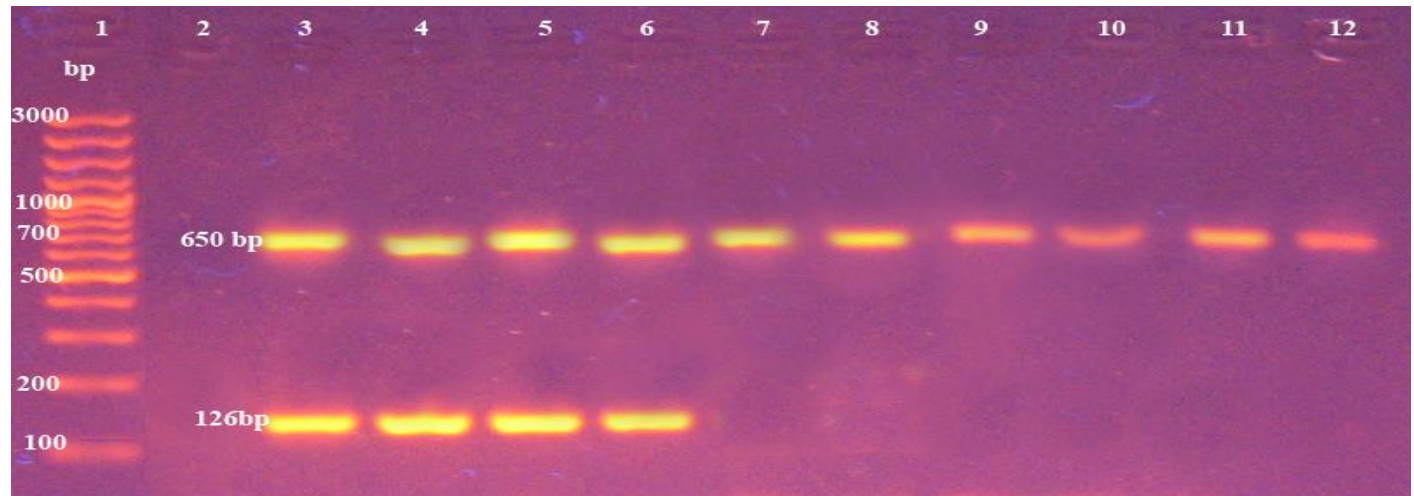

Fig. (2): Agarose gel electrophoresis of multiplex PCR for 23S rRNA at $650 \mathrm{bp}$ and glyA at $126 \mathrm{bp}$ from turkeys. Lane 1: Thermoscientific, GeneRuler 100bp DNA Ladder, (\#SM0243). Lane 2: control Negative. Lane 3: Positive control for $C$. jejuni and $C$. coli. Lanes 4-12: samples positive $C$. jejuni for $23 \mathrm{~S}$ rRNA in all Campylobacter spp. with $C$. coli at 126 bp, except 7- 12 lane has no C. coli.

\section{DISCUSSION}

The prevalence of Campylobacter in turkeys (22.5\%) observed in this study as shown in table (4) is with values reported by Noormohamed and Fakhr (2014) and Logue et al. (2003). The highest incidence was in Dakahlia and Kafr El-Sheikh Governorates 24\% followed by Gharbia $21.5 \%$ and finally in Sharkia $20 \%$ (Table, 4). The prevalence of Campylobacter jejuni in turkeys was $15.4 \%$ which is near from results obtained by Perko-Makela et al. (2009). Campylobacter coli percentage in turkeys was detected as 7\% which was agreement with Atanassova et al. (2007) and Gahlan et al. (2017). The prevalence rate of $C$. jejuni was higher than $C$. coli in this study which agree with Weber et al. (2014). The difference was notably due to a positive hippurate test identified as C.jejuni but absence for C. coli (Table, 6) (Sincinschi, 1995).

Table (6) revealed the high incidence of Campylobacter in liver was $(30 \%)$ followed by skin $(26.7 \%)$, cloacal swabs $(21.3 \%)$ and finally intestinal content $(16.7 \%)$. The high incidence of Campylobacter due to contamination rate attributed to that damage to intestinal tract during evisceration can lead to direct contamination of the carcasses. Contamination can also occur indirectly through the hands of the processors and material or instrument used in processing (Salihu et al., 2009).

The Polymerase Chain Reaction (PCR) technique is the most widely used of all molecular techniques as it is highly sensitive, specific and rapid for the detection of food-borne pathogens (Samosornsuk et al., 2007). The specificity of this assay to detect $C$. coli or C. jejuni was $97 \%$ (Nayak et al., 2005). Table (7) showed the amplification of the DNA belonging to Campylobacter isolates obtained in the present study. This amplification was performed strictly according to the Multiplex PCR methods and amplification parameters as specified by Wang et al. (2002). All samples yielded the genus specific (23S rRNA) with percentage (19\%); (13.8\%) C. jejuni specific at 650 bp and $(5.8 \%) C$. coli specific at 126 bp (Fig. 1 and Fig. 2). These results detected by Waller and Ogata (2000) and Rajagunalan et al. (2014).

PCR analysis detection of Campylobacter can be utilized as a simple and rapid tool to discriminate stains recovered from different sources (French, 2008 and El-Adawy et al., 2012). Finally, we concluded that prevention and control of $C$. jejuni in turkey farms would reduce the risk of human exposure to Campylobacter and is an important food safety issue. Multiplex PCR was found to be more reliable than the conventional cultural methods in species level for identification and differentiation of Campylobacter isolates. Further epidemiological studies at different geographical areas, carried to discover the prevalence, magnitude and importance of Campylobacter infection in turkey farms.

\section{REFERENCES}

Anonymous (2007): Ace Biosciences, Ace393, the World's First Commercial Vaccine for Travellers' Diarrhea Caused by Campylobacter Successfully Completes Phase I Clinical Trials. Clinical trials/ace-biosciences-ace393-440 .

Atanassova, V.; Reich, F.; Beckmann, L. and Klein, G. (2007): Prevalence of Campylobacter spp. in turkey meat from a slaughter hour and in turkey meat retail products. Immunology and Medical Microbiology. V. 49, Issue 1, p. 141145 .

Borck, B. and Pedersen, K. (2005): Pulsed-field gel electrophoresis types of Campylobacter spp. in Danish turkeys before and after slaughter. International Journal of Food Microbiology. V. 101, Issue 1, P. 63-72.

Butzler, J.P. and Oosterom, J. (1991): Campylobacter: pathogenicity and significance in foods. International Journal of Food Microbiology, 12: 1-8. 
El-Adawy, H.; Hotzel, H.; Tomaso, H.; Neubauer, H. and Hafez, H.M. (2012): Elucidation of colonization time and prevalence of thermophilic Campylobacter species during turkey rearing using multiplex polymerase chain reaction. Poult Sci. 91(2): 454-9.

El-Gohary, A.H. (1998): Prospective studies on campylobacteriosis in human and animals in contact. Assuit Vet. Med. J., 38: 192-202.

French, N. (2008): Molecular Epidemiology and Veterinary Public Health Group Enhancing surveillance of potentially foodborne enteric diseases in New Zealand: Human Campylobacteriosis in the Manawatu. Palmerston North (NZ).

Friedman, C.J.; Neiman, J.; Wegener, H.C. and Tauxe, R.V. (2000): Epidemiology of Campylobacter jejuni infections in the United States and other industrialized nations. Campylobacter. Edited by: Nachamkin I, Blaser M.J. 2000, Washington, D.C: ASM Press, 121-138.

Friesema, I.H.M.; Havelaar, A.H.; Westra, P.P.; Wagenaar, J.A. and Van Pelt, W. (2012): Poultry culling and campylobacteriosis reduction among humans, the Netherlands. Emerging Infectious Diseases 18 (3), 466-468.

Gahlan, A.; Sayed, A.S.M.; Ibrahim, A.I. and Sobhy, M.M. (2017): Occurrence of Campylobacter species in chickens by multiplex polymerase chain reaction. Assuit Vet. Med. Vol. 63 (2): 66- 72 .

Gormley, F.J.; Macrae, M.; Forbes, K.J.; Ogden, I.D.; Dallas, J.F. and Strachan, N.J. (2008): Has retail chicken played a role in the decline of human campylobacteriosis? Journal of Applied and Environmental Microbiology, Vol. 74, PP. 383-390.

Griffiths, P.L. and Park, R.W.A. (1990): Campylobacters associated with human diarrheal disease. J. Appl. Bacterial. 69:281301.

Lee, M.D. and Newell, D.G. (2006): Campylobacter in Poultry: Filling an Ecological Niche. Avian Diseases: Vol. 50, (1), pp. 1-9.

Logue, C.M.; Sherwood, J.S.; Elijah, L.M.; Play, P.A. and Dockter, M.R. (2003): The incidence of Campylobacter species on processed Turkey from processing plants in the Midwestern United States. J Appl Microbiol; 95 (2): 23441.

Mead, PS.; Slutsker, L.; Dietz, V.; McCaig, LF.; Bresee, JS.; Shapiro, C.; Griffin, PM. and Tauxe, RV. (1999): Food-related illness and death in the United States. Emerg Infect Dis.5:607-625.

Musgrove, M.T.; Berrang, M.E.; Byrd, J.A.; Stern, N.J. and Cox, N.A. (2001): Detection of Campylobacter spp. in ceca and crops with and without enrichment. Poult. Sci. 80:825828.
Nayak, R.; Stewart, TM. and Nawaz, MS. (2005): PCR identification of Campylobacter coli and Campylobacter jejuni by partial sequencing of virulence genes. Mol Cell Probes. 19(3): 187-93.

Nguyen, T.N.M.; Hotzel, H.; Njeru, J.; Mwituria, J.; El-Adawy, H.; Tomaso, H.; Neubauer, H. and Hafez, M.H. (2016): Antimicrobial resistance of Campylobacter isolates from small scale and backyard chicken in Kenya. Gut Pathog, 8: 39 .

Noormohamed, A. and Fakhr, M.K. (2014): Prevalence and Antimicrobial Susceptibility of Campylobacter spp. in Oklahoma Conventional and Organic Retail Poultry. Open Microbiol J. 31; 8: 130-7.

OIE (3008): Manual of standards for diagnostic tests and vaccine. World organization for animal Health (OIE) $6^{\text {th }}$ Ed. Paris, France.

Perko- Makela, P.; Isohanni, P.; Katzav, M.; Lund, M; Hannien, M.L. and Lyhs, U. (2009): A longitudinal study of Campylobacter distribution in a turkey production chain. Acta Veterinarian Scandinavia.

Poly, F.; Nolla, A.J.; Riddleb, M.S. and Portera, C.K. (2019): Update on Campylobacter vaccine development Human Vaccines and immunotherapeutic, V.15, (6), 1389-1400.

Rahimi, E. and Tajbakhsh, E. (2008): Prevalence of Campylobacter species in poultry meat in the Esfahan city, Iran. Bulg. J. Vet. Med., 11, No 4, 257-262.

Rajagunalan, S.; Bisht, G.; Pant, S.; Singh, S.P.; Singh, R. and Dhama, K. (2014): Prevalence and molecular heterogeneity analysis of Campylobacter jejuni and Campylobacter coli isolated from human, poultry and cattle, in Pantnagar, India. Veterinarian ARTTIV 84(5), 493-504.

Rosenquist, H.; Nielsen, N.L.; Sommer, H.M.; Norrung, B. and Christensen, B.B. (2003): Quantitative risk assessment of human campylobacteriosis associated with thermophilic Campylobacter species in chickens. Int J Food Microbiol., 83: 87-103.

Salihu, M.D.; Junaidu, A.U.; Magajil, A.A.; Abubakar, M.B.; Adamu, A.Y. and Yakubu, A.S. (2009): Prevalence of Campylobacter in poultry meat in Sokoto, Northwestern Nigeria. Journal of Public Health and Epidemiology Vol. 1 (2), pp. 041-045.

Sambrook, J.; Fritsch, E.F. and Maniatis, T. (1989): Molecular colning, A Laboratory Manual, Second ed. Cold Spring Harbour Laboratory Press.

Samosornsuk, W.; Asakura, M.; Yoshida, E.; Taguchi, T.; Nishimura, K.; Eampokalap, B.; Phongsisay, V.; Chaicumpa, W. and Yamasaki, S. (2007): Evaluation of a Cytolethal Distending Toxin (cdt) gene-based sapecies-specific Multiplex-PCR assay for the 
identification of Campylobacter strains isolated from poultry in Thailand. Microbiol Immunol 51: 909-917.

Shane, S.M. and Harrington, K.S. (1998): Campylobacteriosis. In A laboratory manual for the isolation and identification of avian pathogens (D.E. Swayne J.R. Glisson, M.N. Jackwood, J.E. Pearson and W.M. Reed, Eds). American Association of Avian Pathologists, Kennett Square, Pennsylvania, 35-39.

Sincinschi, L. (1995): The comparative identification of Campylobacter Strains by traditional enzymatic tests and the gene amplification reaction. Bacteriologia, Virusologia, Parazitologia, Epidemiologia (Bucuresti) 40, 221-226.

Smibert, R.M. (1974): Campylobacter: In: Berge's Manual of Determinative Bacteriology $8^{\text {th }}$ Ed., Baltimore, Williams and Wilkins 207-211.

Wallace, J.S.; Stanley, K.N. and Jones, K. (1998): The colonization of Turkeys by thermophilic Campylobacters. J. Appl. Microbiol. 85: 224230.

Waller, D.F. and Ogata, S.A. (2000): Quantitative immunocapture PCR assay for detection of Campylobacter jejuni in foods. J. Applied and Environmental Microbiology. Vol. 66 (9): 4115-4118.

Wang, G.; Clark, C.G.; Taylor, T.M.; Pucknell, C.; Barton, C.; Price, L.; Woodward, D.L. and
Rodgers, F.G. (2002): Colony Multiplex PCR Assay for Identification and Differentiation of Campylobacter jejuni, C. coli, C. lari, C. upsaliensis, and C. fetus subsp. Fetus. J. of Clinical Microbiology, Vol. 40: (12) p. 47444747.

Wassenar, T.M. and Newell, D.G. (2007): The Genus Campylobacter. In the Prokaryotes ed. Dworkin, M., Falkow, S., Rosenberg, E., Schleifer, K.H. and Stackebrandt, E. p.119138.

Weber, R.; Auerbach, M.; Jung, A. and Glünder, G. (2014): Campylobacter infections in four poultry species in respect of frequency, onset of infection and seasonality. Berl Munch Tierarztl Wochenschr. 127 (7-8): 257-66.

Zhao, C.; Ge, B.; Villena, J.; Sudler, R.; Yeh, E.; Zhao, S.; White, D.; Wagner, D. and Meng, J. (2001): Prevalence of Campylobacter spp., Escherichia coli, and Salmonella Serovars in Retail Chicken, Turkey, Pork, and Beef from the Greater Washington, D.C., Area. Appl. Environ. Microbiol. 67:12 5431-5436; doi:10.1128/AEM.67.12.5431-5436.2001.

Zoonotic Agents and Antimicrobial Resistance in the European Union in 2004 (2005): Trendes and sources of zoonosis. European Food Safety Authority Journal 2005-310.

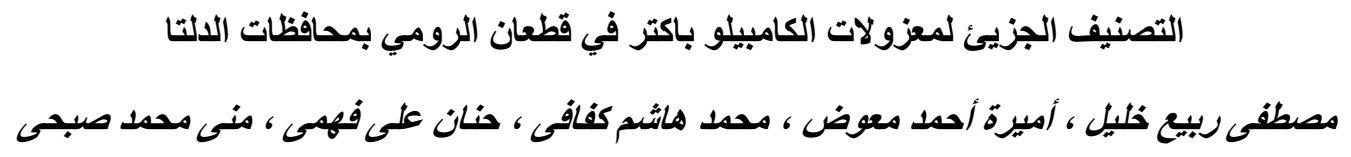

E-mail: monagabr17@yahoo.com Assuit University web-site: $\underline{w w w . a u n . e d u . e g}$

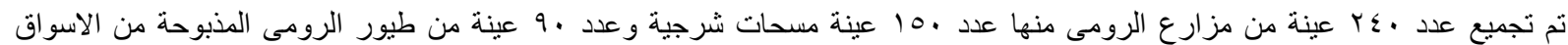

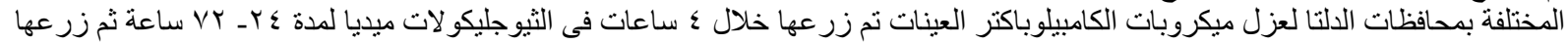

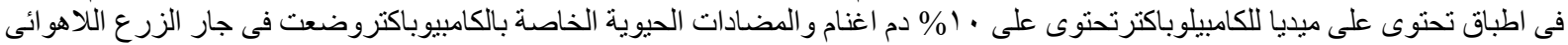

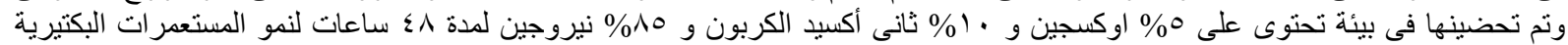

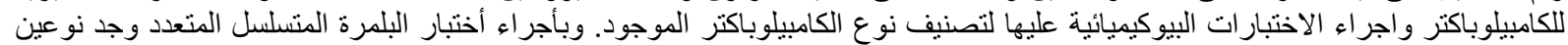

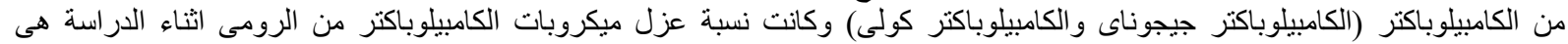

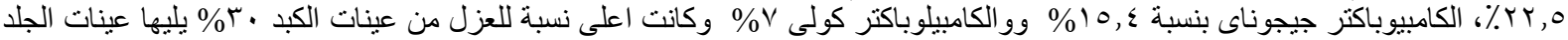

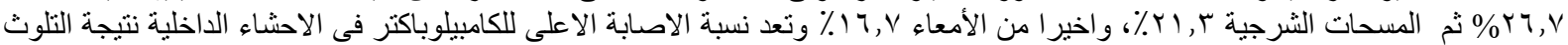

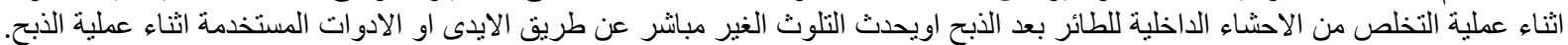

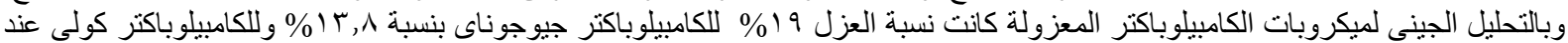
(16SrRNA ) لجين 1632bp323

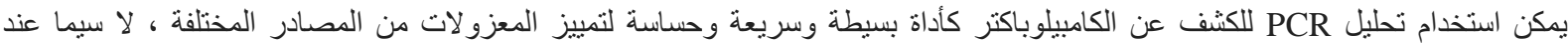

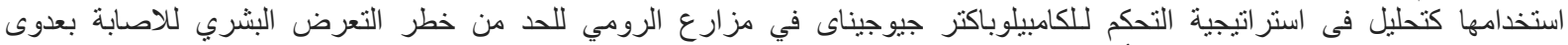

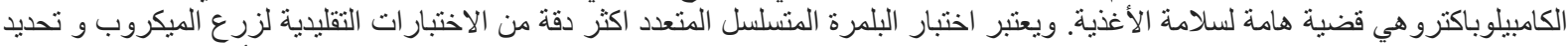

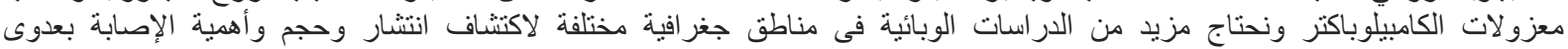

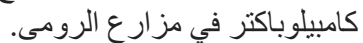


